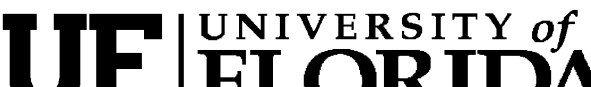 FLORIDA \\ IFAS Extension
}

\section{Goatweed Biology and Control in Pastures ${ }^{1}$}

\section{Brent A. Sellers ${ }^{2}$}

Goatweed (Scoparia dulcis), also referred to as sweet broom and licorice weed, is a perennial plant that is becoming a serious problem in pastures. A problematic weed in citrus groves for many years, goatweed nowappears to be proliferating in improved pastures as the calls for its identification and control have increased greatly over the past couple of years. The spread of goatweed in Florida can be attributed to a number of things including prolific seed production, movement of seeds from citrus groves to pastures through mowing equipment or wildlife, and the tolerance of goatweed to several herbicides utilized in citrus groves and pastures. Goatweed is particularly dense in areas that have been overgrazed or previously harvested for sod.

\section{Biology}

Goatweed seedlings (Figure 1) are extremely small, with opposite or whorled leaves occurring in numbers of three or more on the same node. Leaves are light green, serrated and approximately 1.5 inches long by 1 inch wide (Figure 2). As the plants mature, leaves become linear with or without serrations. Leaves and stems contain small glands that emit an unpleasant odor when crushed. Stems are usually smooth, but sometimes have soft, fine hairs, and become woody with age. Flowers are white, about 3 to $5 \mathrm{~mm}$ long and borne in the leaf axils (Figure 3). Seeds are extremely small and enclosed in a yellow-brown capsule (Figure 4). Perennial goatweed plants at the height of their maturing (Figure 5) look quite different from new seedlings because their leaves have become more linear, giving the plant a spindly appearance. Mature plants reach heights of 1 to 2.5 feet.

Germination of goatweed occurs under light and high temperatures and is inhibited by acidic soils and drought. Since light is a requirement for germination, maintaining a thick grass sward will limit the number of germinating goatweed seeds in pastures. In most cases, goatweed invades areas in pastures where the grass has been killed by overgrazing or other pest problems.

\footnotetext{
1. This document is SS AGR 299, one of a series of the Agronomy Department, Florida Cooperative Extension Service, Institute of Food and Agricultural Sciences, University of Florida. Original publication date February 2008. Visit the EDIS Web Site at http://edis.ifas.ufl.edu.

2. Brent Sellers, assistant professor, Range Cattle Research and Education Center, Institute of Food and Agricultural Sciences, University of Florida, Ona, FL. The use of trade names in this publication is solely for the purpose of providing specific information. UF/IFAS does not guarantee or warranty the products named, and references to them in this publication does not signify our approval to the exclusion of other products of suitable composition. All chemicals should be used in accordance with directions on the manufacturer's label.
}

The Institute of Food and Agricultural Sciences (IFAS) is an Equal Opportunity Institution authorized to provide research, educational information and other services only to individuals and institutions that function with non-discrimination with respect to race, creed, color, religion, age, disability, sex, sexual orientation, marital status, national origin, political opinions or affiliations. U.S. Department of Agriculture, Cooperative Extension Service, University of Florida, IFAS, Florida A. \& M. University Cooperative Extension Program, and Boards of County Commissioners Cooperating. Larry Arrington, Dean 


\section{Control}

Goatweed is relatively tolerant to many of the herbicides utilized in citrus and pastures compared to other weed species. For example, 3 to $4 \mathrm{lbs}$ per acre of glyphosate are needed to control this weed in citrus groves, whereas many other weeds can be controlled with less than $1 \mathrm{lb}$ per acre. In bahiagrass pastures, 4 pints/acre of 2,4-D is needed for optimum control. In bermudagrass and stargrass, Cimarron ${ }^{\circledR}$ at 0.3 oz/acre plus 2 pints/acre 2,4-D provides optimum control of goatweed. The only option for control of goatweed in limpograss (Hemathria) is 0.3 oz/acre of Cimarron. Repeated mowing does not control goatweed either,and it is more difficult to control with herbicides if its stem has become woody. Although Remedy ${ }^{\circledR}$ and Pasturegard ${ }^{\circledR}$ provide good control of most woody species in pastures, these herbicides are not particularl yeffective on goatweed. The best herbicides option for goatweed control is 4 pints/acre of 2,4-D amine. However, if this rate of 2,4-D is to be applied to limpograss, only apply it during cool periods of the year (December through April). while proper pasture management can go a long way in controlling this weed, herbicides with the prescribed amounts of 2,4-D will optimize goatweed control in most improved pastures.

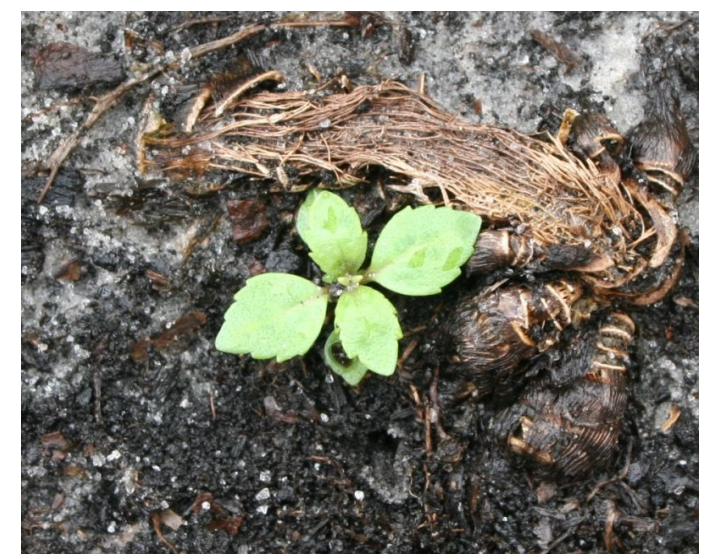

Figure 1. A goatweed seedling approximately 1 week after emergence

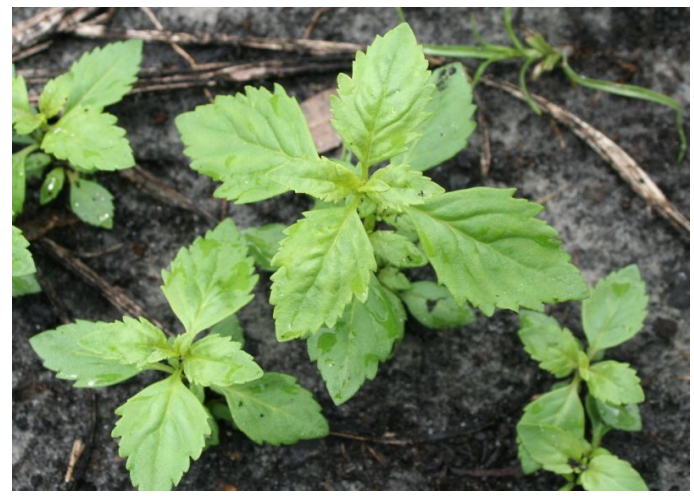

Figure 2. Goatweed leaves are serrated and approximately 1.5 inches long by 1 inch wide. Young plants tend to be light green in color

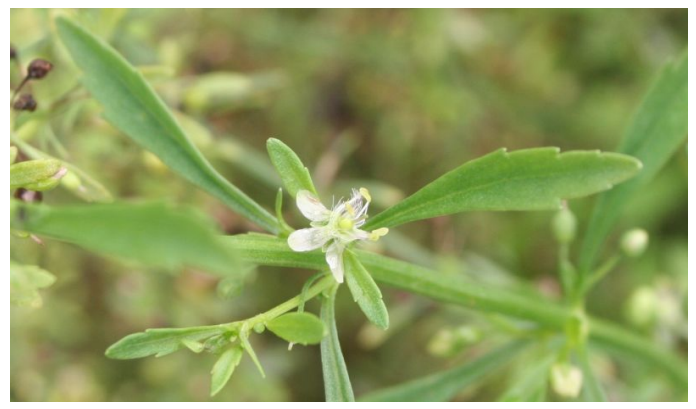

Figure 3. Goatweed flowers are white and are borne in the leaf axils.

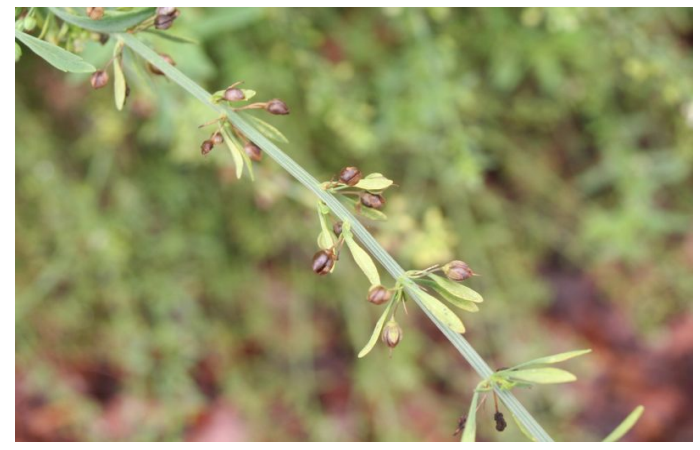

Figure 4. Goatweed seeds are very small and are enclosed in yellow to brown capsules. 


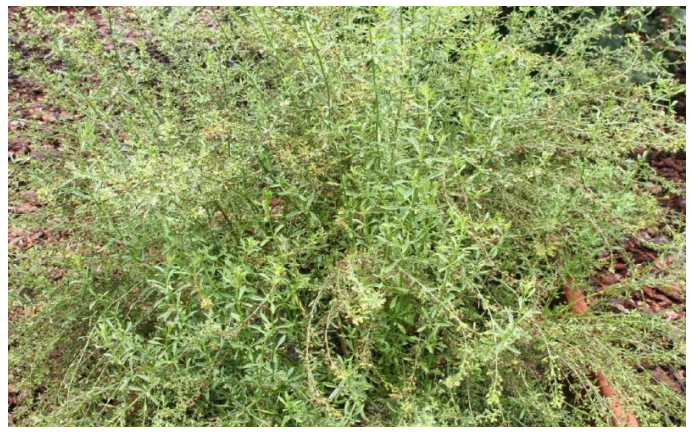

Figure 5. Mature goatweed plants have a more spindly appearance than seedlings. This is due to the linear leaves the plant develops as it matures. 